\title{
Psikolojik Sermayenin İş Performansına Etkisi: Sağlık Çalışanlarında Bir Uygulama*
}

\author{
Mesut KARAMAN ${ }^{* *}$, Mustafa MACIT ${ }^{* * *}$, Hilal KUŞCU KARATEPE ${ }^{* * * *}$ \\ ÖZ
}

$\mathrm{Bu}$ çalışma, sağlık çalışanlarında psikolojik sermayenin iş performansına etkisini belirlemek amacıyla yapılmıştır. Çalışmaya katılmayı kabul eden sağlık kurumlarının farklı birimlerinde çalışmakta olan sağlık çalışanı sayıs1 137'dir. Çalışmada, Luthans vd., (2007)'nin geliştirmiş olduğu Türkçe'ye uyarlaması ise Çetin ve Basım (2012) tarafından yapılan "Psikolojik Sermaye Ölçeği" ve Tercan (2017) tarafından geliştirilen "İ̧ş Performansı Ölçeği" kullanılmıştır. Çalışma sonucunda psikolojik sermaye ölçeği ile cinsiyet, eğitim durumu, toplam mesleki yıl ve bulundukları kurumda çalışma süresi arasında istatiksel olarak anlamlı bir fark olduğu belirlenmiştir. Psikolojik sermayenin iș performansı üzerinde istatiksel olarak anlamlı ve pozitif yönlü bir etkisinin olduğu belirlenmiștir. Psikolojik sermayenin alt bileşenlerinden öz yeterlilik ve umut istatiksel olarak iş performansını anlamlı ve pozitif yönde etkilemektedir. Buna göre psikolojik sermayenin ve alt boyutlarının iş performansının arttırılmasında katkısı olacağı söylenebilir.

Anahtar Kelimeler: Sağlık Çalışanları, Pozitif Psikoloji, Psikolojik Sermaye, İş Performansı, Regresyon Analizi

JEL Sinıflandırmasi: M1, M12, M54

\section{The Effect of Psychological Capital on Business Performance: An Application in Health Care Workers}

\section{ABSTRACT}

This study was carried out to determine the effect of psychological capital on job performance in health care workers. The number of health workers working in different units of health institutions that accepted to participate in the study was 137. In the study, Turkish version of the "Psychological Capital Scale" developed by Luthans et al. (2007) that adapted into Turkish by Çetin and Basım (2012) and" Work Performance Scale 'developed by Tercan (2017) were used. As a result of the study, it was determined that there was a statistically significant difference between the psychological capital perception and gender, educational status, total professional year and the duration of work in the institution. It was determined that psychological capital had a statistically significant and positive effect on job performance. The self-efficacy and hopes of the sub-components of psychological capital are statistically significant and positively affect on the work performance. Therefore, it can be said that psychological capital and its sub-dimensions would contribute to increase work performance.

Keywords: Health Workers, Positive Psychology, Psychological Capital, Work Performance, Regression Analysis

JEL Classification: M1, M12, M54

Geliş Tarihi / Received: 12.05.2019 Kabul Tarihi / Accepted: 10.09.2019

\footnotetext{
* Bu çalışmanın bir bölümü Mesut Karaman tarafından Kahramanmaraş Sütçü İmam Üniversitesi Sosyal Bilimler Enstitüsü’nde tamamlanmış olan "Psikolojik Sermaye ve Maneviyat Algısının Algılanan Performansa Etkisi: Sağlık Çalışanlarında Bir Uygulama" başlıklı yüksek lisans tezinden türetilmiştir.

*** (Sorumlu Yazar) Bilim Uzmanı, Sütçü İmam Üniversitesi, Sosyal Bilimler Enstitüsü, Sağlık Yönetimi Anabilim Dal1, mesut karaman66@hotmail.com, ORCID: 0000-0001-6154-8940.

**** Dr. Öğr. Üyesi, Sütçü İmam Üniversitesi, İktisadi ve İdari Bilimler Fakültesi, Sağlık Yönetimi Bölümü mustafamacit@ksu.edu.tr, ORCID: 0000-0002-5672-5161.

**** Öğr. Gör., Osmaniye Korkut Ata Üniversitesi, Sağlık Bilimleri Fakültesi, Hemşirelik Bölümü, hkuscukaratepe@osmaniye.edu.tr, ORCID: 0000-0001-9237-2714.
} 


\section{GİRIŞ}

Rekabet ortamının giderek arttığı günümüz iş ortamında yaşanan hızlı değişimler ve teknolojik gelişmeler ile birlikte değişen koşullara işletmelerin de uyum sağlaması bir zorunluluk haline gelmiştir. Rekabet ortamı içerisinde işletmeler, varlıklarını devam ettirebilmek için birtakım kaynakları elde etmek ve bu kaynakları etkin bir şekilde kullanmak yönünde yeni arayışlar içerisine girmişlerdir. İşletmeler yoğun iş temposu altında sürekli değişen talep ve ihtiyaçlara cevap verebilmek için tüm çalışanlarıyla birlikte performanslarını en üst seviyede gerçekleştirmek noktasında çabalarını sürdürmektedirler. $\mathrm{Bu}$ süreçte çalışanlar arasında psikolojik olarak etkilenme, performans düşüklüğü, verim kaybı gibi bir takım olumsuz faktörler yaşanabilmektedir. Yaşanan bu ve buna benzer olumsuz faktörleri en alt seviye çekebilmek ve önüne geçebilmek için işletmeler rakiplerine karşı maksimum performans sağlayacak yeni yöntemler arayışı içerisindedirler (Akçay, 2012: 124).

Performans arttırma ve işletmelerin etkililiğini ve verimini yükseltmek için son yıllarda önemle üzerinde durulan konulardan biri de psikolojik sermayedir. İşletme yöneticileri bireylerin sahip olduğu sermaye türlerinden (sosyal ve beşerî sermaye) daha ötesinde olan psikolojik sermaye sayesinde çalışanların performansını arttırma, bireylerin olumlu yönlerini ortaya çıkarma, bireylerin pozitif yönde meydana gelen gelişmişlik düzeylerini yükseltmek gibi olumlu sonuçların ortaya çıkarılması ve artırılması gayreti içerisindedirler. Alan yazınında yapılan incelemelerde bireyin performansının arttırılmasına yönelik psikolojik sermayenin önemli bir belirleyici olduğu görülmektedir (Erkmen ve Esen, 2013: 23). Bu uygulamaların artırılması ile çalışanların performansının arttırılması ile işletmenin belirlemiş olduğu hedefleri gerçekleştirilmesi mümkün olabilecek, ayrıca işlerinde başarılı olan bireylerin işletmeye olan bağglılığının daha da artacağı ifade edilebilir. Bu bağlamda hizmet sektörünün önemli bir alanı olan sağl1k sektörünün hizmet sunumunda insan unsurunun ne denli önem arz ettiği dikkate alındığında bu konunun sağlık işletmeleri için daha bir dikkatle ele alınmasının gerekliliği kendiliğinden ortaya çıkmaktadır. Sorumluluk bilinci üst düzeyde olan çalışanlarla verilen hizmetlerin daha başarılı sonuçlar ortaya koyacağı söylenebilir. Bu sayede sağlık kurumlarının hem bireysel hem de kurumsal anlamda performanslarını daha bir üst düzeye taşınması mümkün olabilecektir.

Sağlık hizmetlerinin yapısının dinamikliği ve artan sağlık kuruluşlarının sayısı düşünüldüğünde kaliteli bir hizmet sunumu işletmelerin rekabette başarılı olması için önemlidir (Atlı ve Yücel, 2018: 47). Kaliteli hizmet sunma bağlamında da sağlık kuruluşları arasında da bir rekabetin olduğu unutulmamalıdır. Sağlık kuruluşlarından bireylerin beklenti ve ihtiyaçları dikkate alındığında mevcut insan kaynağı ve imkânlarla artan talepler karşısında çalışanlar performanslarını üst düzeyde sergilemeleri gerekmekte ve belirli bir süre sonra performans düşüklügü gibi olumsuz faktörlerle karşı karşıya kalabilmektedirler. Psikolojik sermaye bu noktada yöneticilere çalışanları için performans yönetimi ve performansı arttırmaya yönelik önemli bir yol göstericidir (Öğüt ve Kaplan, 2015: 87). Psikolojik sermaye, hizmet almak isteyen bireylerden gelen yoğun talepler karşısında çalışanın yaşayabileceği tükenmişliği minimum seviyeye indirmek, hizmet talebinde bulunan bireylere güler yüzlü ve olumlu bir yaklaşım sergilemek, yaşanan zaman israfı kayıplarının önüne geçmek ve sınırlı imkânlarla üst düzey hizmet sunmak için kurum çalışanlarına ve yöneticilerine önemli bir rehberdir denilebilir.

Psikolojik sermaye alanında yapılan birçok araştırmadan hareketle ulaşılan ortak görüş; psikolojik sermayenin işletmeler açısından sürdürülebilir bir büyümeyi ve gelişmeyi sağlamak için ihtiyaç duyulan performansın sağlanmasında kilit rol oynadığıdır. Diğer bir ifadeyle, psikolojik sermaye, değişen dünya koşullarında kuruluşların yönetim sürecine ilişkin hedefleri gerçekleştirmede yeni perspektifler ortaya koymaya ve geliştirmeye ciddi katkılar sağlayacak nitelikte önemli bir avantaj sunmaktadır (Akdemir ve Açan, 2017: 58). Bu çalışmada psikolojik sermayenin ve boyutlarının iş performansı üzerine etkisinin ne düzeyde olduğunun belirlenmesi 
amaçlanmıştır. Araştırmada psikolojik sermaye ve performans hakkında gerekli literatür bilgisi verildikten sonra araştırmanın yöntemi hakkında bilgi verilmiştir. Takip eden bölümlerde araştırmanın bulgu ve tartışmalarına yer verilmiştir. Araştırmanın kısıtlarına değinilerek gerek araştırmacı gerekse uygulamacılara yönelik sonuç ve önerilere yer verilerek çalışma son bulmuştur.

\section{KAVRAMSAL ÇERÇEVE}

\subsection{Psikolojik Sermaye}

1900'lü yılların başında psikoloji bilim dalı, insanlar için nelerin iyi olarak nitelendirilebileceği ve insanın kendi potansiyelini gerçekleştirebilmesi için ne gibi faktörlerin etkili olduğu konusundaki sorulara daha yoğun bir ilgi göstermeye başlamıştır. Günümüzde iş hayatının gelişimine yönelik, insan kaynaklarının psikolojik kapasiteleri ve olumlu yönleri üzerinde yapılan çalışmalar neticesinde pozitif yönelimli bir kavram olan psikolojik sermaye kavramı ortaya çıkmıştır (Özkan, 2018: 25). Psikolojik sermaye bireylerin psikolojik anlamda olumlu yönde meydana gelen gelişmesini ifade etmektedir. Bireylerin en zor görevleri alabilmesi, bu görevleri yerine getirebilmesi için sahip oldukları geleceğe dair pozitif duygular, güven duygusu ve yüz yüze geldikleri sıkıntı ve problemlerle mücadele ederek yaşamını sürdürmek psikolojik sermayenin olumlu yönünü oluşturmaktadır (Öğe ve Kaplan, 2017: 31). Psikolojik sermeye "bireyin pozitif psikolojik gelişim durumu" olarak tanımlanmıştır (Luthans vd., 2007: 542). Bu tanımlamalar doğrultusunda psikolojik sermayenin bireylerin üstlendikleri zor görevler karşısında olumlu yönlerini ortaya koyabilme ve bu olumlu yönler ile engelleri aşabilmeleri için önemli bir güç unsuru olarak da değerlendirebilir.

Bir dizi bireysel niteliği kapsayan psikolojik sermaye üretkenliği de doğrudan etkilemektedir. Bu özelliği ile psikolojik sermaye verimliliğin sağlanması için hem sosyal, beşerî ve finansal sermayeden başarılı biçimde yararlanmak, hem de çalışanların gerekli yetenek ve görüşlerini kuruma taşıyabilme yeteneği şeklinde de tanımlanabilmektedir (Luthans vd., 2006: 387). Bu sermaye türü işletmelerin rekabet üstünlüğü sağlamalarına yönelik sermaye türlerine ilave olarak (insan, sosyal ve ekonomik sermaye) ortaya çıkmıştır (Kutanis ve Oruç, 2014: 150). $\mathrm{Bu}$ bağlamda belirtilen insan, sosyal ve ekonomik sermaye yanında ve hatta daha da ötesinde psikolojik sermayenin gerekliliğinden söz edilebilir.

Psikolojik sermaye kavramı, bireysel ve örgütsel düzeyde pozitif bir bakış açısını savunmaktadır. Psikolojik sermaye kavramını diğer pozitif örgütsel davranışlardan ve diğer sermaye türlerinden ayıran bir takım özellikler mevcuttur. Bunlar Büyükgöze (2014: 19-21)'e göre;

Psikolojik sermayenin sosyal ve beşerî sermayeden fazlasını ifade etmesi,

Pozitif, kendine özgü ve yaratıcı olması,

Psikolojik sermayenin kuram ve araştırmaya dayanması, ölçülebilir, durum-temelli ve geliştirilebilir olması,

Çalışanların iş performansı üzerinde etkili olmasıdır.

Psikolojik sermaye öz yeterlilik, umut, iyimserlik ve dayanıklılık bileşenleri şeklinde dört alt boyuttan oluşmaktadır (Luthans, Luthans ve Luthans, 2004:47). Takip eden bölümde bu alt boyutlar açıklanmıştır.

Umut; bireyin hem kendisi hem de örgütü için değerli amaçları belirleyebilmesi ve bu amaçları elde etmek için zorlukların üstesinden gelebilme inancını (başarma gücü) içeren motivasyonel bir durumdur (Çetin ve Basım, 2012: 126). Luthans vd., (2007) umut düzeyi 
yüksek olan çalışanların gelir seviyeleri az olsa bile çalışmalarına yeteneklerini yansıtan bireyler olduklarını belirtmişlerdir. Bunun temel nedeni olarak umut düzeyi yüksek olan çalışanların risk alabilen, özgür düşünceye sahip, başarısızlıkla neticelenen işlerde bile diğer alternatif yolları tercih edebilen ve uygulayan, yaratıcılık özelliğiyle problemler karşısında yeni çözümler getirebilen kişiler olmasıdır (Aktaran Özkan, 2018: 35). Dolaysıyla umut düzeyi yüksek çalışanların görevlerine daha sıkı bir şekilde bağl1, daima olumlu duygular besleyen ve işletmeler açısından önemli bir başarı kaynağı olduğu söylenebilir.

Bir kişilik özelliği veya genel bir tutum olarak tanımlanan iyimserlik; bireylerin yaşadıkları olumlu olayları içsel, kalıcı ve yaygın nedenlerle ilişkilendirirken, olumsuz olarak yaşanan olayları ise dışsal, geçici ve belirli koşullara bağlamalarıyla ilgilidir. İyimserlik yüksek performans elde edilmesinin olası öncüllerinden biridir ve başarıyı elde etmek için bir firsat olarak algılanmaktadır (Erkuş ve Fındıklı, 2013: 305). İyimserliğin bazı olumsuz yönleri de bulunmaktadır. Örneğin birey fiziki açıdan hiçbir sorun yaşamadığı için sağlığı hakkında oldukça iyimser davranacak ve herkesin alması gereken önlemleri göz ardı edebilecektir. Bunun sonucunda karşılaştığ kötü bir durum ve sağlık problemi sonucunda beklemediği sonuçlarla karşılaşabilecektir. Ya da işletmelerde yöneticinin iyimser olması önlem almaması ve hedeflere ulaşmak için gerekeni yapmamasına neden olabilmekte, işletmede istenmeyen durumlar oluşabilmektedir. Bu olumsuzluklarla karşı karşıya kalmamak için bireylerin daha esnek ve daha realist bir şekilde düşünmesi ve iyimserliğin olumlu ve olumsuz sonuçlarını titizlikle incelemesi gerekmektedir (Luthans, 2002: 64-65). Bu kapsamda örgüt yöneticileri yaşanabilecek problemlerin üstesinden gelebilecekleri yönünde olumlu duygular beslemeli ancak bunun gerçekçi olup olmadığını da her zaman sorgulamadırlar. Gerçekçi olmayan olumlu beklentilerin sonuçta geri dönülemez birtakım olumsuzluklara (verimsizlik, motivasyon düşüklüğü, rekabette başarısızlık vb. gibi) yol açma ihtimali de dikkate alınarak hareket edilmelidir.

Psikolojik dayanıklılık; bireylerin tehlikeli durumları, güçlükleri ve değişimi başarılı bir şekilde atlatmalarını sağlayan pozitif psikolojik kapasiteyi ifade etmektedir. Psikolojik dayanıklılık zaman içerisinde çevresel ve bireysel faktörlerden etkilenerek olumlu gelişme gösterebilmekte ve değişim geçirebilmektedir. Dayanıklılık bireylerin maruz kaldıkları olumsuz şartlar altındaki durumlara karşı göstermiş oldukları uyum olarak da tanımlanabilir (Keleş, 2011: 348). Dayanıklılık sadece olumsuz durumlar karşısında dayanıklı olmak ve bu durumları atlatmak ile sınırlı değildir, ayrıca pozitif durumların atlatılmasını da kapsamaktadır. Bir başka tanımda ise dayanıklılık, bireylerin etrafında meydana gelen pozitif ve negatif olaylara gösterdiği direncidir (Luthans, Norman ve Avolio, 2008: 222). Dayanıklı1ık kavramının yalnızca olumsuz durumlara yönelik değil olumlu durumları da içerdiği görülmektedir. İnsanlar işten çıkarılma, amaçlara ulaşamama, takım arkadaşları tarafından görmezden gelinme gibi olumsuz olaylara karşı koyarken, iş ile ilgili sorumluluklardaki önemli bir artış, hedeflerle ilgili önemli beklentilerin gerçekleşmesi gibi konularla da dayanıklılık sayesinde önemli bir kazanım sağlarlar (Luthans, Youssef ve Avolio, 2007: 121). Psikolojik dayanıklılık, bu yüzden, hem olumsuz olayların sonuçlarıyla başa çıkmada hem de artan, yeni sorumlulukların üstesinden gelmek için de çalışanlar açısından önemli bir avantaj sağlamaktadır.

Öz yeterlilik kavramını literatüre kazandıran A. Bandura'nın (1982: 122) tanımıyla öz yeterlilik "gelecekteki durumlarla başa çıkabilmek için gereken eylem planlarını ne kadar iyi uygulayabileceğine" dair kişisel bir yargıdır (aktaran Stajkovic ve Luthans, 1998b:240). Stajkovic ve Luthans (1998a: 60) ise öz yeterliliği belirli bir görevin başarılı bir şekilde yapılmasında bireyin ihtiyaç duyulan motivasyon, bilişsel kaynaklar ve gereken faaliyetleri yerine getirmek konusunda güven ve kabiliyetleri olarak tanımlamaktadırlar. Kendilerini yeterli olarak algılayan bireyler, eğer uygulamayı da başarı ile yerine getirmişlerse, başarılı sonuçlar orya koyan çabayı üretecek, düşük öz yeterlilik algılayanlar ise çabalarını erken durduracak ve görevlerinde büyük ihtimalle başarısız olacaklardır (Stajkovic ve Luthans, 1998b: 240). Öz yeterlilik kişiyi zorlu hedefler belirleme ve bunların üstesinden gelmek için güçlü yönlerini ve 
becerilerini kullanmaya motive eder. Bireye hedeflerini gerçekleştirme yönünde enerji sağlar ve azimle çalışmaya teşvik edici bir görev üstlenir. Engellerle karşılaştı̆̆ında vazgeçmesini önleyerek, hedeflerini korumasını sağlar. Öz yeterlilik kendi kendine öğrenilebilir ve zaman içerisinde geliştirilebilir. Bireyin kendisinin kim olduğunu tanımasını sağlayacak ve küçük müdahalelerle değiştirilebilecek ve geliştirilebilecek bir farkındalıktır (Luthans, Youssef, Avolio, 2007: 34). Stajkovic ve Luthans (1998b: 240) öz yeterliliğin iş performansı üzerine etkisiyle ilgili yapılan 114 ampirik çalışmayı incelemişler ve öz yeterliliğin iş performansı üzerinde güçlü pozitif bir etkisi olduğu sonucuna ulaşmışlardır. Öz yeterlilik çalışanın üstelenmiş olduğu görevini başarı ile tamamlaması için sahip olduğu donanımlardır. Bu öz yeterliliğin performans üzerinde güçlü bir etkisinin olduğu görülmektedir.

\subsection{Performans Kavramı ve Kapsamı}

Örgüt yönetiminde performans son derece önemlidir, çünkü gerek bireysel gerekse örgütsel anlamda yapılan çalışmaların belirli düzeylerde gerçekleşmesi amaçlanmaktadır. Belirlenen standartların altında kalan çabaların hem birey hem de işletmeler için olumsuz sonuçlar doğuracağı yadsınmamalıdır. Performans, belirlenen şartlar çerçevesinde bir işin yerine getirilme düzeyi veya çalışanın davranış biçimi olarak tanımlanabilir (Ertuğrul, 2006: 156). Sonnentag ve Frese (2002: 18) ise performansı bireyin örgütsel amaçlarla örtüşen ölçülebilir davranışları şeklinde tanımlamaktadırlar. Harvey ve Bowin (1996: 140)'a göre performans bir çalışanın belirli bir zaman diliminde kendisine verilen görevle ile ilgili belirlenmiş faaliyet ve ulaşılması arzulanan sonuçları başarmasıdır. Öğüt ve Kaplan (2015: 91)'a göre belirli bir işin yerine getirilmesi ve tamamlanması olan iş performansı, bireyin görevini gerçekleştirmesi için harcadığ1 tüm çabalar karşısında elde ettiği başarı düzeyidir. Çalışanın üstelenmiş olduğu herhangi bir işi yerine getirmesi sonucunda başarı düzeyini dolayısıyla performansında artışını netice verecektir.

İşletmeler amaçlarını geçekleştirebilmek, uzman oldukları alanlarda mal ve hizmet sunabilmek ve rekabet avantajı sağlayabilmek için yüksek performans gösteren bireylere ihtiyaç duyarlar. Performans bireyler için de önem arz eden bir olgudur. Sahip olunan görevleri üst düzeyde ve başarılı bir şekilde yerine getirmek bireyler açısından tatmin kaynağı, uzmanlık göstergesi ve övünç kaynağı olacaktır. Tersi bir durum ise hem kişisel anlamda başarısızlık hem de tatminsizlik kaynağı olacaktır. Çalışanın üst düzey performansı kariyer ve finansal anlamda da kazanımları beraberinde getirecektir (Sonnentag ve Frese, 2002: 4). İşletmelerin içinde bulundukları dinamik çevrede şartlarında rakiplerin sayısı ger geçen artmakta ve işletmeler arası yoğun bir rekabet kaçınılmaz hale gelmektedir. Rekabet ortamında işletmelerin ayakta kalabilmeleri, varlıklarını devam ettirebilmeleri için belirlemiş olduğu hedeflere ulaşma gayesiyle en alt basamaktan en üst basamağa kadar bütün çalışanların etkinlik, verimlilik ve etkililik ilkeleri doğrultusunda bir performans yönetimi esas alınmalıdır (Helvacı, 2002: 156). $\mathrm{Bu}$ bağlamda işletmelerin başarısının bireysel ve dolayısıyla kurumsal anlamda çalışanların üst düzey performans göstermeleriyle yakından ilgili olduğu söylenebilir.

\subsection{Psikolojik Sermayenin İş Performansına Etkisi}

Çok boyutlu ve dinamik bir kavram olmasından dolayı performansı etkileyen farklı değişkenler söz konusudur. Bunlar arasında işin özellikleri, bireyle ve çevre ile ilgili etkenler sayılabilir (Sonnentag ve Frese, 2002:15). Bu çalışmanın temel sorunsalı psikolojik sermayenin performans üzerine etkisini ortaya çıkarmak olduğu için birey ile ilgili psikolojik sermaye bağlamındaki özellikler dikkate alınmıştır. Literatür incelemesi sonucunda psikolojik sermayenin performans algısına etkisi sağlık sektörü ve farklı sektörlerde araştırılmıştır. Konuya yönelik yapılan çalışmalara aşağıda yer verilmiştir. 
Peterson vd., (2011)'nin yaptıkları araştırmada büyük bir finansal hizmet kuruluşunda çalışan 179 finansal danışmanın zaman içinde psikolojik sermayedeki bireysel değişikliği ve bu değişikliğin performanstaki değişim ile ilişkili olup olmadığı incelenmiştir. Araştırma sonuçlarına göre; zaman içinde psikolojik sermayenin bireysel olarak değiştiği ve bu değişimin, danışman tarafından derecelendirilen performans ve finansal performansı, yani bireysel satış geliri ile ilişkisinin de istatistiksel olarak anlamlı olduğu ortaya çıkmıştır.

Erkuş ve Fındıklı (2013) tarafından yapılan çalışmada, psikolojik sermayenin iş tatmini ve işten ayrılma niyeti üzerindeki etkisinin belirlenmesi amaçlanmıştır. Farklı sektörlerde 572 çalışan dâhilinde yapılan çalışma sonucunda; psikolojik sermaye ile iş performansı, iş tatmini arasında anlamlı düzeyde pozitif bir ilişki belirlenmiştir. Katılımcıların psikolojik sermaye düzeyleri ile işten ayrılma niyeti arasında ise negatif yönde istatiksel olarak anlamlı bir ilişki ortaya çıktığı görülmüştür.

Uğurlu Kara (2014)'nın çalışmasında 150 çalışan dâhilinde veriler elde edilmiştir. Araştırma sonuçları neticesinde; psikolojik sermaye ile bireysel performans arasında istatiksel açıdan anlamlı orta düzeyde pozitif yönlü bir ilişki bulunmuştur. Regresyon analizi sonuçları incelendiğinde, psikolojik sermayenin bireysel performansı istatiksel olarak anlamlı ve pozitif yönde etkilediği görülmüştür.

Ögüt ve Kaplan (2015) tarafindan yapılan çalışmada sağlık çalışanlarında psikolojik sermayenin iş performansı üzerindeki etkisi belirlenmeye çalışılmıştır. Bu amaçla 278 sağlık çalışanının katkıda bulunduğu araştırma sonuçları incelendiğinde; psikolojik sermaye ölçeği alt boyutlarından iyimserlik ve öz yeterliliğin iş performansı üzerinde anlamlı bir şekilde pozitif yönde etkiye sahip olduğu belirlenirken, umut ve psikolojik dayanıklılığın iş performansı üzerinde anlamlı bir etkiye sahip olmadığı belirlenmiştir.

Durrah vd., (2016) psikolojik sermayenin iş performansına etkisini belirlemek amacıyla 110 öğretim üyesi dahilinde bir araştırma yapmışlardır. Psikolojik sermaye ölçeği alt boyutlarından psikolojik dayanıklılık, öz yeterlilik ve umut alt boyutları iş performansını pozitif yönde etkilerken, iyimserlik alt boyutunun iş performansını etkilemediği görülmüştür.

Korkmazer vd., (2016)'nin psikolojik sermayenin çalışan performansına etkisini belirlemeye yönelik sağlık çalışanlarında yapmış oldukları çalışmada; 152 sağlık çalışanından elde edilen veriler kapsamında, psikolojik sermayenin tüm alt boyutlarıyla (dayanıkl111k, iyimserlik, umut ve öz yeterlilik) çalışan performansındaki değişimlerin \% 47'sini açıkladığı belirlenmiştir.

Saithong-in (2016) psikolojik sermayenin iş performansına etkisini incelemiştir. Tayland'da 102 mali müşavirden elde edilen veriler sonucunda psikolojik sermayenin iş performansı üzerinde olumlu bir etkisinin olduğu ortaya konmuştur.

Ateş vd., (2018) tarafından yürütülen çalışmada, lojistik sektöründe 1401 katılımcı dahilinde psikolojik sermayenin iş performansına etkisinde örgütsel özdeşlemenin aracılık rolü belirlenmeye çalışılmıştır. Psikolojik sermayenin umut, iyimserlik, öz yeterlilik ve psikolojik dayanıklılık alt boyutları ile iş gören performansı arasında örgütsel özdeşlemenin dolaylı etkisinin olduğu araştırmanın sonuçları arasındadır. Ayrıca çalışmanın psikolojik sermaye ölçeği alt boyutlarının oluşturmuş olduğu çalışma ortamındaki sinerji ile psikolojik dayanıklılık, iyimserlik, umut ve öz yeterlilik alt bileşenlerinin çalışanların performansı ve örgütsel özdeşleşme üzerinde istatiksel açıdan anlamlı ve pozitif yönde etkiye sahip olduğu görülmüştür.

Karatepe vd., (2018) tarafından yapılan çalışmada 130 hemşire dahilinde psikolojik sermayenin bireysel performans üzerindeki etkisi ortaya konulmaya çalışılmıştır. Yapılan çalışma sonucunda hemşirelerde psikolojik sermayenin bireysel performansı istatiksel olarak anlamlı ve pozitif yönlü olarak etkilediği belirlenmiştir. Psikolojik sermaye ölçeği alt 
boyutlarından ise öz yeterlilik alt boyutunun bireysel performansı istatiksel olarak anlamlı ve pozitif yönde etkilediği saptanmıştır.

Sağl1k hizmetlerinin sunumunda insan unsurunun son derece önemlidir ve bireysel performansı açıklamakta önemli bir değişken olarak beliren psikolojik sermaye konusundaki çalışmaların azlığı dikkate alınarak sağlık sektöründe psikolojik sermayenin performans üzerine etkisini ortaya koymaya yardımcı olacak bir çalışmanın hem literatür hem de uygulama açısından faydalı olacağı düşünülmüştür. Yapılan literatür taramasında da psikolojik sermaye ile performans arasındaki ilişkinin yönü dikkate alınarak bu çalışmada "Psikolojik sermayenin performans algısı üzerinde istatiksel olarak anlamlı bir etkisi var mıdır?" sorusunun cevabı bulunmaya çalışılmıştır. Araştırmanın amacı ve literatürde değinilen çalışmaların sonuçları doğrultusunda geliştirilen araştırma hipotezleri aşağıda verilmiştir (Tablo 1).

Tablo 1: Araştırma Kapsamında Geliştirilen Hipotezler

\begin{tabular}{cl}
\hline $\mathrm{H}_{1}$ & $\begin{array}{l}\text { Psikolojik sermaye algısının iş performansı algısı üzerinde istatiksel olarak pozitif ve anlamlı } \\
\text { bir etkisi vardır. }\end{array}$ \\
\hline $\mathrm{H}_{1 \mathrm{a}}$ & $\begin{array}{l}\text { Psikolojik sermaye ölçeği dayanıklılık alt boyutunun iş performansı algısı üzerinde istatiksel } \\
\text { olarak pozitif ve anlamlı bir etkisi vardır. }\end{array}$ \\
\hline $\mathrm{H}_{1 \mathrm{~b}} \quad \begin{array}{l}\text { Psikolojik sermaye ölçeği iyimserlik alt boyutunun iş performansı algısı üzerinde istatiksel } \\
\text { olarak pozitif ve anlamlı bir etkisi vardır. }\end{array}$ \\
\hline $\mathrm{H}_{1 \mathrm{c}} \quad \begin{array}{l}\text { Psikolojik sermaye ölçeği umut alt boyutunun iş performansı algısı üzerinde istatiksel olarak } \\
\text { pozitif ve anlamlı bir etkisi vardır. }\end{array}$ \\
\hline $\mathrm{H}_{1 \mathrm{~d}} \quad \begin{array}{l}\text { Psikolojik sermaye ölçeği öz yeterlilik alt boyutunun iş performansı algısı üzerinde istatiksel } \\
\text { olarak pozitif ve anlamlı etkisi vardır. }\end{array}$ \\
\hline
\end{tabular}

\section{YÖNTEM}

Tanımlayıcı tipteki bu araştırma tarama modeli ile gerçekleştirilmiştir. Bu çalışmada sağlık çalışanlarının psikolojik sermaye algılarının iş performansı üzerine etkilerinin belirlenmesi amaçlanmıştır. Araştırma evrenini Hatay ilinde 2 özel hastane de çalışan 300 sağ lık çalışanı oluştururken, araştırmada rassal örneklem yöntemi ile 26.03.2018-01.06.2018 tarihleri arasında 137 katılımcıya gönüllülük esas alınarak ulaşılmıştır. Veri toplama aracı olarak kişisel bilgi formu, psikolojik sermaye ve iş performansı ölçeği kullanılmıştır. Psikolojik Sermaye algısının ölçülmesinde Luthans vd. (2007)'nin geliştirmiş olduğu Çetin ve Basım (2012)'ın ise Türkçe'ye uyarladığı Psikolojik Sermaye Ölçeği kullanılmıştır. Likert tipi olarak geliştirilen ölçeğin puanlaması "1 Hiç Katılmıyorum" dan "6 Tamamen Katılıyorum" arasında olacak şekildedir. Psikolojik sermaye ölçeğinin dört faktörlü yapısına yönelik yapı geçerliliği ise, doğrulayıcı faktör analizi (DFA) ile test edilmiştir. Yapılan DFA sonucunda elde edilen uyum iyiliği değerleri şu şekildedir; $[\chi 2=302,326 ; \mathrm{Sd}=173 ; \chi 2 / \mathrm{Sd}=1,84 ; \mathrm{AGFI}=0,86 ; \mathrm{GFI}=0,88$; $\mathrm{CFI}=0,94 ; \mathrm{IFI}=0,95$; RMSEA=0,06; RMR=0,07]. DFA analizi sonucunda elde edilen uyum iyiliği değerlerine bakılarak psikolojik sermaye ölçeğinin dört faktörlü yapısı doğrulanmış ve ölçeğin geçerli bir ölçek olduğu sonucuna ulaşılmıştır.

İş Performansı Ölçeği ise tek boyutlu olarak Tercan (2017)'nın geliştirdiği ve yine Tercan (2017) tarafından ölçeğin puanlaması da "(1) Hiç Yansıtmıyor"dan “(5) Tamamen Yansitıyor" arasında puanlaması yapılan ölçektir. Performans ölçeğinin tek faktörlü yapısına 
yönelik yapı geçerliliği ise, doğrulayıcı faktör analizi (DFA) ile test edilmiştir. Yapılan DFA sonucunda elde edilen uyum iyiliği değerleri şu şekildedir; $[\chi 2=64,673 ; \mathrm{Sd}=34 ; \chi 2 / \mathrm{Sd}=1,80$; AGFI $=0,92 ; \quad$ GFI $=0,96 ; \quad$ CFI $=0,95 ; \quad I F I=0,95 ; \quad$ RMSEA $=0,07 ; \quad$ RMR $=0,04] . \quad$ DFA analizi sonucunda elde edilen uyum iyiliği değerlerine bakılarak iş performansı ölçeğinin tek faktörlü yapısı doğrulanmış ve ölçeğin geçerli bir ölçek olduğu sonucuna ulaşılmıştır.

Araştırmaya başlamadan önce Kahramanmaraş Sütçü İmam Üniversitesi Bilimsel Araştırmalar Etik Kurulu'dan 14/03/2018 tarihli ve E.10371 sayılı etik kurul izni ile araştırmanın yapıldığı kurumlardan yazılı izinler alınmıştır. Verilerin değerlendirilmesinde SPSS 22 paket programından yararlanılmıştır. Analiz işleminden önce normallik testi uygulanmıştır. Psikolojik sermaye ve iş performansı ölçek değişkenlerinden elde edilen verilerin Skewness (çarpıklık) ve Kurtosis (basıklık) değerlerinin normallik testi sonucunda $-1,5$ ile $+1,5$ arasında değer aldıkları görülmüştür (Tablo 2). Tabachnick ve Fidell (2013)'e göre ölçek değişkenlerinden elde edilen verilerin Skewness (çarpıklık) ve Kurtosis (basıklık) değerleri -1,5 ile $+1,5$ arasında değer alırsa normal dağılım şartını sağlamaktadır. Verilerin analiz edilmesinde kullanılan analiz yöntemleri; sayı-yüzdelik hesaplama, bağımsız örneklem $\mathrm{t}$ testi, tek yönlü varyans analizi, pearson korelasyon analizi, basit ve çoklu regresyon analizi yöntemlerinden yararlanılmıştır. Verilerin Cronbach Alfa değerleri incelenmiş olup Tablo 1'de sunulmuştur. Psikolojik sermaye ve iş performansı ölçekleri için Cronbach Alfa değerleri 0,64 ile 0,92 değişmektedir. Macit (2015:123-124)'e göre Cronbach Alfa değeri $0,60 \leq \alpha \leq 0,80$ ise ölçek oldukça güvenilirdir.

Tablo 2: Ölçeklerin Cronbach Alfa, Skewness ve Kurtosis Değerleri

\begin{tabular}{lccc}
\hline & Cronbach Alfa & Skewness & Kurtosis \\
\hline Dayanıkl1lik & 0,82 & $-1,006$ & 1,523 \\
\hline İyimserlik & 0,64 & $-0,045$ & $-0,216$ \\
\hline Umut & 0,79 & $-0,394$ & $-0,636$ \\
\hline Öz yeterlilik & 0,91 & $-0,465$ & $-1,115$ \\
\hline Psikolojik sermaye & 0,92 & $-0,498$ & $-0,802$ \\
\hline İş performansı & 0,89 & $-1,026$ & 0,561 \\
\hline
\end{tabular}

Araştırmada kullanılan ölçeklerin Cronbach Alfa değerleri incelendiğinde ölçeklerin oldukça güvenilir olduğu söylenebilir.

\section{BULGULAR VE TARTIŞMA}

Katılımcıların sosyo-demografik özellikleri Tablo 3'de verilmiştir. Tablo 3 incelendiğinde katılımcıların \%70,1'i kadın \%29,9'u erkektir. Araştırmaya dâhil olan sağlık çalışanlarının \%50,4'ü bekâr \% 49,6'sı evlidir. Katılımcıların \%35'8'i 23-28 yaş, yine \%35,8'i yüksekokul mezunudur. Katılımcıların toplam mesleki yıl olarak \%42,3'ü 1-5 yıl, \%25,3'ü 6-10 yıl arasında ve \%13,1'i 11-15 yıl arasındadır. Bulundukları kurumda çalışma süresi olarak ise \%47,4’ü 1-5 yıl, \%32,8'i 6-10 yıl ve \%19,7'si 1 yıldan az olduğu tespit edilmiştir.

Katılımcıların psikolojik sermaye puan ortalamaları ile cinsiyetleri arasında anlamlı bir farklılık belirlenmiştir (T:-2,163; P:0,032). Psikolojik sermayenin erkek katılımcılarda $(4,89 \pm 0,53)$ anlamlı düzeyde daha yüksek olduğu belirlenmiş ve bulgunun literatür ile uyumlu olduğu görülmüştür (Erkmen ve Esen 2012; Örgün vd., 2017). 
Sağlık çalışanlarının medeni durumları ile psikolojik sermaye puan ortalamaları arasında anlamlı bir fark bulunmamıştır (T:-1,551; P:0,123). Türesin vd. (2017)'nin çalışmasında ise katılımcıların medeni durumları ile psikolojik sermaye puan ortalamaları arasında istatiksel olarak anlamlı bir fark olduğu belirlenmiştir. Tekin (2018)'nin çalışmasında katılımcıların medeni durumları ile psikolojik sermaye ölçeği arasında anlamlı bir fark olduğu saptanmıştır. Dolayısıyla bu çalışmanın bu yöndeki bulguları literatür ile uyum göstermemektedir. Bu konuda yapılacak yeni çalışmalarla bu konu daha ayrıntılı şekilde ortaya konulabilir.

Katılımcıların psikolojik sermaye ölçeği puan ortalamaları ile yaş grupları arasında istatiksel açıdan anlamlı bir fark olmadığ görülmüştür (F:0,593; P:0,254). Enderoğlu (2018)'nun çalışmasında ise katılımcıların yaşları ile psikolojik sermaye algıları arasında anlamlı bir fark olmadığ

Sağlık çalışanlarının psikolojik sermaye puan ortalamaları ile eğitim durumları arasında anlamlı bir fark olup (F:3,183; P:0,045) lisans mezunlarında $(4,94 \pm 0,61)$ psikolojik sermayenin anlamlı düzeyde daha yüksek olduğu görülmüsstür. Gruplar arası farklılığı belirlemek amacıyla yapılan Tukey testi analizinde; katılımcıların psikolojik sermaye düzeylerinin eğitim durumu alt değişkenlerinde, yüksekokul ile lisans mezunları arasındaki ortalama puan farkı lisans mezunları lehine istatistiksel olarak anlamlı düzeyde yüksek olduğu bulunmuştur. Nitekim Karadal ve Öz Sungur (2017)'un çalışmasında da katılımcıların eğitim durumları ile psikolojik sermaye ölçeği arasında anlamlı bir fark olduğu belirlenmiştir.

Katılımcıların psikolojik sermaye puan ortalamaları ile toplam mesleki yıl süresi arasında istatiksel açıdan anlamlı bir fark olup (F:3,460; P:0,010), toplam mesleki y1l süresi 1-5 y1 arası $(4,91 \pm 0,59)$ olanlarda psikolojik sermaye puan ortalamasının anlamlı düzeye daha yüksek olduğu belirlenmiştir. Tukey testi analizi sonuçlarına göre; katılımcıların psikolojik sermaye düzeylerinin toplam mesleki y1l alt değişkenlerinde, 1-5 yıl ile 6-10 yıl grupları arasındaki ortalama puan farkı istatistiksel olarak anlamlı bulunmuştur. Kaya vd. (2014)'nin çalışması ile Erkmen ve Esen (2012)'nin çalışmasında katılımcıların toplam mesleki çalışma yılı ile psikolojik sermaye düzeyleri arasında anlamlı bir fark belirlenirken, Argon ve Tükel (2016)'in çalışmasında ise katılımcıların toplam mesleki yıl süreleri ile psikolojik sermaye ölçeği arasında anlamlı bir fark olmadığı görülmüş̧ür.

Sağlık çalışanlarının psikolojik sermaye puan ortalamaları ile bulundukları kurumda çalışma süresi arasında istatiksel açıdan anlamlı bir fark olduğu saptanmıştır (F:3,475; P:0,034). Bulundukları kurumda çalışma süresi $1-5$ yıl arası $(4,85 \pm 0,60)$ olan katılımcılarda psikolojik sermaye algısının anlamlı düzeyde daha yüksek olduğu belirlenmiştir. Tukey testi analizi sonuçlarına göre; katılımcıların psikolojik sermaye düzeylerinin toplam mesleki yıl alt değişkenlerinde, 1-5 yıl ile 6-10 yıl grupları arasındaki ortalama puan farkı istatistiksel olarak anlamlı bulunmuştur. Elde edilen araştırma bulgusu literatür tarafından destelenmiştir (Turgut vd., 2016; Yıldız ve Örücü, 2016; Örgün vd., 2017).

Katılımcıların psikolojik sermaye ölçeği puan ortalamaları ile çalışma statüsü arasında anlamlı bir fark (F:3,432; P:0,019) olduğu, çalışma statüsü yardımcı sağlık personeli olanlarda psikolojik sermaye algısının $(4,89 \pm 0,49)$ anlamlı düzeyde daha yüksek olduğu bulgulanmıştır. Tukey testi analizi sonuçlarına göre; katılımcıların psikolojik sermaye düzeylerinin çalışma statüsü alt değişkenlerinde, yardımcı sağlık personeli ile ofis çalışanı grupları arasındaki ortalama puan farkı istatistiksel olarak anlamlı bulunmuştur. Literatürde farklı sektörlerde yapılan çalışmalar incelendiğinde de katılımcıların çalışma statüsü ile psikolojik sermaye düzeyleri arasında anlamlı bir fark olduğu görülmüştür (Yıldız ve Örücü, 2016; Türesin vd., 2017; Topkaya ve Korucu, 2018). 
Tablo 3. Katılımcıların Sosyo-Demografik Özellikleri ile Ölçekler Arasında Yapılan Analiz Sonuçları

\begin{tabular}{|c|c|c|c|c|c|c|}
\hline \multirow[b]{2}{*}{$\begin{array}{l}\text { Sosyo-demografik } \\
\text { Değişken }\end{array}$} & \multirow[b]{2}{*}{$\mathrm{N}$} & \multirow[b]{2}{*}{$\%$} & \multicolumn{2}{|c|}{ Psikolojik Sermaye } & \multicolumn{2}{|c|}{ Performans } \\
\hline & & & Ortalama \pm ss & $\begin{array}{l}\text { Test ve } p \\
\text { değeri }\end{array}$ & Ortalama \pm ss & $\begin{array}{l}\text { Test ve } p \\
\text { değeri }\end{array}$ \\
\hline \multicolumn{7}{|l|}{ Cinsiyet $* *$} \\
\hline Kadın & 96 & 70,1 & $4,63 \pm 0,66$ & $\mathrm{~T}:-2,163$ & $4,43 \pm 0,52$ & $\mathrm{~T}:-0,537$ \\
\hline Erkek & 41 & 29,9 & $4,89 \pm 0,53$ & P:0,032* & $4,48 \pm 0,50$ & P:0,592 \\
\hline \multicolumn{7}{|l|}{ Medeni durum ** } \\
\hline Evli & 68 & 49,6 & $4,62 \pm 0,70$ & $\mathrm{~T}:-1,551$ & $4,39 \pm 0,53$ & $\mathrm{~T}:-1,145$ \\
\hline Bekar & 69 & 50,4 & $4,79 \pm 0,56$ & P:0,123 & $4,49 \pm 0,49$ & P:0,254 \\
\hline \multicolumn{7}{|l|}{ Yaş*** } \\
\hline $18-22$ yaş & 35 & 25,5 & $4,81 \pm 0,62$ & & $4,51 \pm 0,44$ & \\
\hline $23-28$ yaş & 49 & 35,8 & $4,68 \pm 0,63$ & $\mathrm{~F}: 1,950$ & $4,38 \pm 0,58$ & $\mathrm{~F}: 0,593$ \\
\hline 29-34 yaş & 31 & 22,6 & $4,83 \pm 0,52$ & P:0,125 & $4,50 \pm 0,44$ & P:0,620 \\
\hline $35-40$ yaş & 22 & 16,1 & $4,45 \pm 0,77$ & & $4,41 \pm 0,55$ & \\
\hline \multicolumn{7}{|l|}{ Ĕgitim durumu ${ }^{* * *}$} \\
\hline Lise & 42 & 30,7 & $4,61 \pm 0,58$ & & $4,52 \pm 0,51$ & \\
\hline Yüksekokul & 49 & 35,8 & $4,60 \pm 0,67$ & $\mathrm{~F}: 3,183$ & $4,36 \pm 0,54$ & $\mathrm{~F}: 1,068$ \\
\hline Lisans & 46 & 33,6 & $4,94 \pm 0,61$ & P:0,045* & $4,47 \pm 0,48$ & P:0,347 \\
\hline \multicolumn{7}{|l|}{ Toplam mesleki yıl ${ }^{* * *}$} \\
\hline 1 yıldan az & 14 & 10,2 & $4,41 \pm 0,66$ & & $4,39 \pm 0,56$ & \\
\hline $1-5$ yıl arası & 58 & 42,3 & $4,91 \pm 0,59$ & $\mathrm{~F}: 3,460$ & $4,50 \pm 0,51$ & $\mathrm{~F}: 0,324$ \\
\hline 6-10 y1l aras1 & 35 & 25,5 & $4,49 \pm 0,62$ & P:0,010* & $4,39 \pm 0,53$ & P:0,861 \\
\hline $11-15$ yıl aras 1 & 18 & 13,1 & $4,69 \pm 0,69$ & & $4,39 \pm 0,48$ & \\
\hline 16 ve üstü & 12 & 8,8 & $4,73 \pm 0,52$ & & $4,48 \pm 0,53$ & \\
\hline \multicolumn{7}{|l|}{$\begin{array}{l}\text { Bulundukları kurumda } \\
\text { çalışma süresi }{ }^{* * *}\end{array}$} \\
\hline 1 yıldan az & 27 & 19,7 & $4,66 \pm 0,57$ & & $4,48 \pm 0,35$ & \\
\hline $1-5$ yıl arasi & 65 & 47,4 & $4,85 \pm 0,60$ & $\mathrm{~F}: 3,475$ & $4,52 \pm 0,48$ & $\mathrm{~F}: 2,147$ \\
\hline $6-10$ y1l aras1 & 45 & 32,8 & $4,53 \pm 0,68$ & P:0,034* & $4,32 \pm 0,62$ & P:0,121 \\
\hline \multicolumn{7}{|l|}{ Çalışma statüsü̈*** } \\
\hline Yardımcı sağlık personeli & 51 & & $4,89 \pm 0,49$ & $\mathrm{~F}: 3,432$ & $4,52 \pm 0,45$ & $\mathrm{~F}: 4,845$ \\
\hline Ebe & 22 & & $4,78 \pm 0,43$ & P:0,019* & $4,61 \pm 0,38$ & P:0,003* \\
\hline Teknisyen & 38 & & $4,61 \pm 0,78$ & & $4,45 \pm 0,52$ & \\
\hline Ofis Çalışanı & 26 & & $4,44 \pm 0,69$ & & $4,13 \pm 0,59$ & \\
\hline
\end{tabular}

$* \mathrm{p}<0,05 * *$ t testi $* * *$ tek yönlü varyans analizi 
Tablo 3'te verilen analiz sonuçlarına göre, katılımcıların performans algıları ile çalışma statüsü arasında anlamlı bir fark (F:4,845; P:0,003) olduğu görülmüş, çalışma statüsü ebe olarak görev yapanların performans algısı $(4,61 \pm 0,38)$ anlamlı düzeyde daha yüksek bulunmuştur. Katılımcıların performans algısı puan ortalaması ile cinsiyet, medeni durum, eğitim düzeyi, yaş, toplam mesleki yıl ve bulundukları kurumda çalışma süresi arasında istatiksel açıdan anlamlı bir fark olmadığ 1 belirlenmiş ve bulgunun literatür ile uyumlu olduğu görülmüştür (Kılınç ve Paksoy 2017; Tercan 2017; Uğurlu Kara 2014; Saygıl1 vd., 2016).

Aşağıdaki Tablo 4'te psikolojik sermaye ölçeği ve performans algısı ölçekleri arasındaki pearson korelasyon analizi sonuçlarıyla birlikte araştırmada kullanılan ölçeklerin puan ortalamaları gösterilmiştir. Tablo 4 incelendiğinde psikolojik sermaye puan ortalaması $(\bar{X}=4,71 \pm 0,63)$ olarak bulunmuştur. Sağlik sektöründe yapılan çalışmalar incelendiğinde; psikolojik sermaye puan ortalamaları, Korkmazer vd. (2016)'ın çalışmasında ( $\overline{\mathrm{X}}=3,87 \pm 0,47)$, Yıldız ve Örücü (2016)'nün çalışmasında $(\bar{X}=3,98)$, Cömert ve Yürür (2017)'ün çalışmasında $(\bar{X}=3,92 \pm 0,83)$, Özer vd. (2013)'nin çalışmasında $(\bar{X}=4,44 \pm 0,68)$, Uğan vd. (2018)'ın çalışmasında $(\overline{\mathrm{X}}=4,19 \pm 0,44)$ ve Karatepe vd. (2018)'nin çalışmasında $(\overline{\mathrm{X}}=4,43 \pm 0,71)$ olarak tespit edilmiştir.

Tablo 4: Psikolojik Sermaye ve Performans Algısı Arasındaki Pearson Korelasyon Analizi Sonuçları ve Ölçeklerin Puan Ortalamaları

\begin{tabular}{|c|c|c|c|c|c|c|c|c|}
\hline & Ortalama \pm ss & & 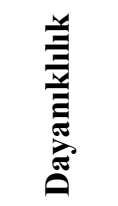 & 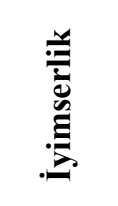 & $\vec{\Xi}$ & 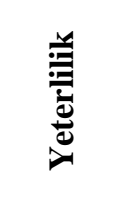 & 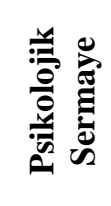 & 离 \\
\hline \multirow{2}{*}{ Dayanıklılık } & \multirow{2}{*}{$4,78 \pm 0,91$} & $\mathrm{r}$ & 1 &, $235^{* *}$ &, $552^{* *}$ &, $591^{* *}$ &, $786^{* *}$ &, $397^{* *}$ \\
\hline & & $\mathrm{p}$ & & ,006 &, 000 & ,000 &, 000 &, 000 \\
\hline \multirow{2}{*}{ İyimserlik } & \multirow{2}{*}{$4,00 \pm 0,70$} & $\mathrm{r}$ &, $235^{* *}$ & 1 &, $458^{* *}$ &, $333^{* *}$ &, $607^{* *}$ &, $274^{* * *}$ \\
\hline & & $\mathrm{p}$ & ,006 & & ,000 & ,000 &, 000 & ,001 \\
\hline \multirow{2}{*}{ Umut } & \multirow{2}{*}{$5,00 \pm 0,75$} & $\mathrm{r}$ &, $552^{* *}$ &, $458^{* *}$ & 1 &, $755^{* *}$ &, $875^{* *}$ & $607^{* *}$ \\
\hline & & $\mathrm{p}$ & ,000 &, 000 & & ,000 &, 000 & ,000 \\
\hline \multirow{2}{*}{ Yeterlilik } & \multirow{2}{*}{$5,05 \pm 0,86$} & $\mathrm{r}$ &, $591^{* * *}$ &, $333^{* *}$ &, $755^{* *}$ & 1 &, $865^{* *}$ &, $664^{* *}$ \\
\hline & & $\mathrm{p}$ & ,000 & ,000 & ,000 & &, 000 & ,000 \\
\hline \multirow{2}{*}{$\begin{array}{l}\text { Psikolojik } \\
\text { Sermaye }\end{array}$} & \multirow{2}{*}{$4,71 \pm 0,63$} & $\mathrm{r}$ &, $786^{* *}$ &, $607^{* *}$ &, $875^{* *}$ &, $865^{* *}$ & 1 &, $622^{* *}$ \\
\hline & & $\mathrm{p}$ & ,000 &, 000 &, 000 & ,000 & & ,000 \\
\hline \multirow{2}{*}{ Performans } & \multirow{2}{*}{$4,44 \pm 0,51$} & $\mathrm{r}$ &, $397^{* *}$ &, $274^{* *}$ &, $607^{* *}$ &, $664^{* *}$ &, $622^{* *}$ & 1 \\
\hline & & $\mathrm{p}$ & ,000 & 001 & ,000 & ,000 &, 000 & \\
\hline
\end{tabular}

$* * p<0,01$ 
Performans algısı puan ortalaması ise, $(\overline{\mathrm{X}}=4,44 \pm 0,51)$ olarak hesaplanmıștır. Alan yazını incelendiğinde bu değerler; Kılınç ve Paksoy (2017) sağlık çalışanlarında $(\bar{X}=4,21 \pm 0,78)$, Tercan (2017)'nın çalışmasında ( $\bar{X}=4,18 \pm 0,66)$ ve Tekingündüz vd., (2015)'nin çalışmasında $(\overline{\mathrm{X}}=4,25 \pm, 60)^{\prime}$ 'dır. Araştırma bulgularından hareketle elde edilen puan ortalamalarının literatür ile uyumlu olduğu ifade edilebilir.

Hemşirelerin psikolojik sermaye ölçeği ile performans ölçeği arasındaki ilişkiyi ortaya koymak amaçlı yapılan pearson korelasyon analizi sonuçları Tablo 4'de sunulmuştur. Tablo 4 incelendiğinde; psikolojik sermaye ölçeği dayanıklılık, iyimserlik, umut ve yeterlilik alt boyutları arasında istatiksel olarak anlamlı ve pozitif yönlü ilişkinin olduğu belirlenmiştir (Tablo 4; $\mathrm{p}<0,01)$. Dolayısıyla psikolojik sermaye ölçeğinin alt boyutlarının herhangi birisindeki artışla psikolojik sermayenin de aynı şekilde artacağı ifade edilebilir. Katılımcıların performans algısı ile psikolojik sermaye ölçeği arasında istatiksel açıdan anlamlı ve pozitif yönlü bir ilişkinin olduğu tespit edilmiştir (r:0,622; p:0,000). Korelasyon analizleri neticesinde; en yüksek ilişki düzeyi performans algısı ile öz yeterlilik alt boyutundadır. En zayıf ilişki düzeyi ise performans algısı ile iyimserlik alt boyutundadır (Tablo 4).

Psikolojik sermayenin performans algısına etkisini ortaya koymak amaçlı basit doğrusal regresyon analizi yapılmıştır. Basit doğrusal regresyon analizi modeli $\mathrm{Y}=\mathrm{a}+\mathrm{bX}$ (Alpar, 2018) şeklinde tanımlanmaktadır.

Tablo 5 incelendiğinde; psikolojik sermayenin performans algısına etkisini ortaya koymak amaçlı kurulan basit doğrusal regresyon analizi modeli (F:85,141; p:0,000) ve test $(\mathrm{t}: 9,227 ; \mathrm{p}: 0,000)$ değeri istatiksel açıdan anlamlıdır. Psikolojik sermaye ve performans algısı arasında pozitif yönlü anlamlı bir ilişki vardır (R:0,622; P:0,000).

Tablo 5: Psikolojik Sermayenin Algilanan Performansa Etkisi

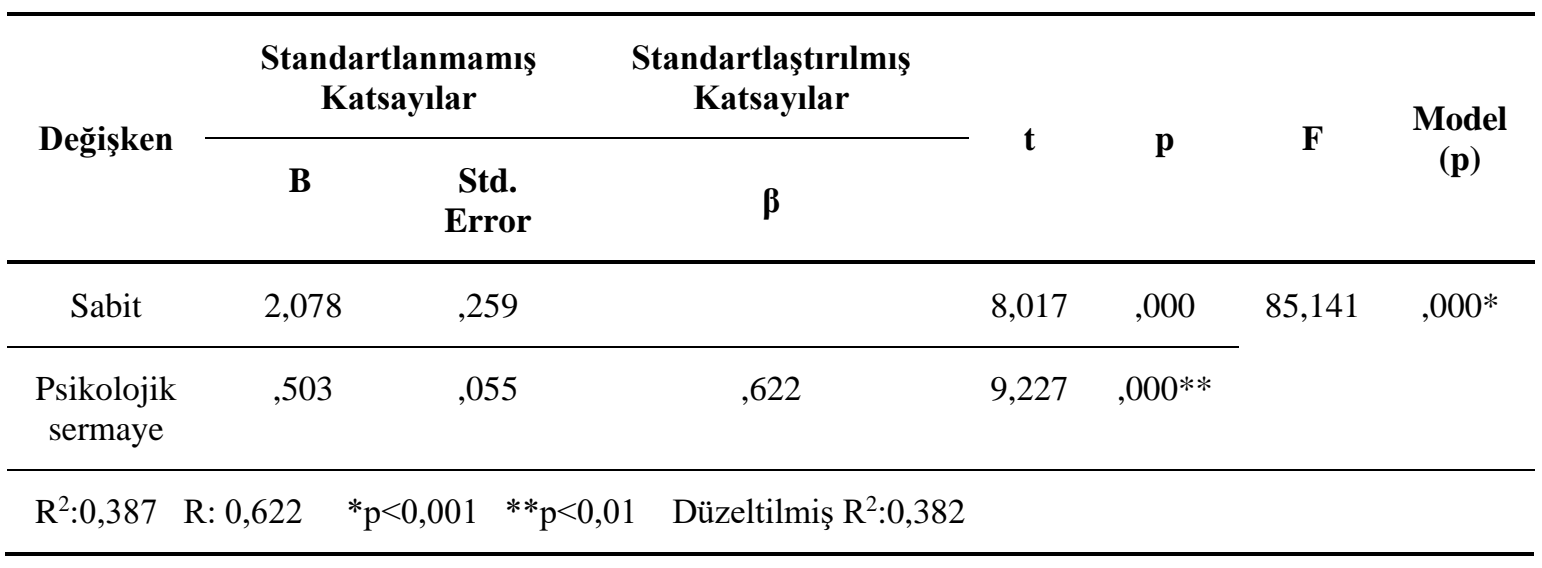

Modelin belirlilik katsayısı $\mathrm{R}^{2}: 0,387$ olarak hesaplanmıştır. $\mathrm{Bu}$ sonuca göre; katılımcıların performans algısındaki değişimlerin \%38,7'si psikolojik sermaye ile açıklanmaktadır. Psikolojik sermayedeki bir birimlik artış katılımcıların performans algılarını 0,503 birim arttırmaktadır. Sonuç olarak; katılımcıların psikolojik sermaye düzeylerinin performans algıları üzerinde pozitif yönlü ve istatiksel olarak anlamlı bir etkisinin olduğu saptanmış ve literatür ile de uyumlu bulunmuştur (Kormazer vd., 2016; Öğüt \& Kaplan, 2015; Uğurlu Kara, 2014; Erkuş \& Findıkl1, 2013; Uğur, 2017; Karatepe vd., 2018; Uğan vd., 2018). Yapılan regresyon analizi sonucu Tablo 2 de verilen $\mathrm{H}_{1}$ hipotezi yani, "Psikolojik sermaye algısının iş performansı algısı üzerinde istatiksel olarak pozitif ve anlamlı bir etkisi vardır." şeklinde belirlenen hipotez kabul edilmiştir. Regresyon analizi sonucuna göre tahmin edilmiş 
model; $Y=a+b X$ (Alpar, 2018) ise, $a: 2,078$ ve b:0,503 olmak üzere $Y=2,078+0,503 \quad X^{\prime}$ dir ( $\mathrm{X}=$ Psikolojik Sermaye).

Psikolojik sermaye ölçeği (dayanıklılık iyimserlik, umut ve yeterlilik) alt boyutlarının algılanan performansa etkisini ortaya koymak için çoklu regresyon analizi yapılmıştır (Tablo 6). Analiz işlemine geçilmeden önce analiz kriterleri olan Durbin-Watson katsayısı (oto-korelasyon) ve Varyans Şişme Faktör (Variance Inflation Factor-VIF) katsayılarına bakılmıştır. Varyans Şişme Faktör (Variance Inflation Factor-VIF) katsayılarının 10'dan az olması ve Durbin-Watson katsayısının 1,5 ile 2,5 arasında olması çoklu bağlantı ve otokolerasyon problemlerinin olmadığını gösterir (Korkmazer vd., 2016). Bu çalışmada Durbin-Watson katsayısı 1,736 olarak elde edilmiş ve VIF değerleri ise; 1,226 ile 2,716 arasında değişmekte olduğu görülmüştür. Buna göre elde edilen veriler incelendiğinde otokolerasyon ve çoklu bağlantı problemlerinin olmadığ 1 ifade edilebilir.

Tablo 6: Psikolojik Sermaye Ölçeği Alt Boyutlarının Algılanan Performansa Etkisi

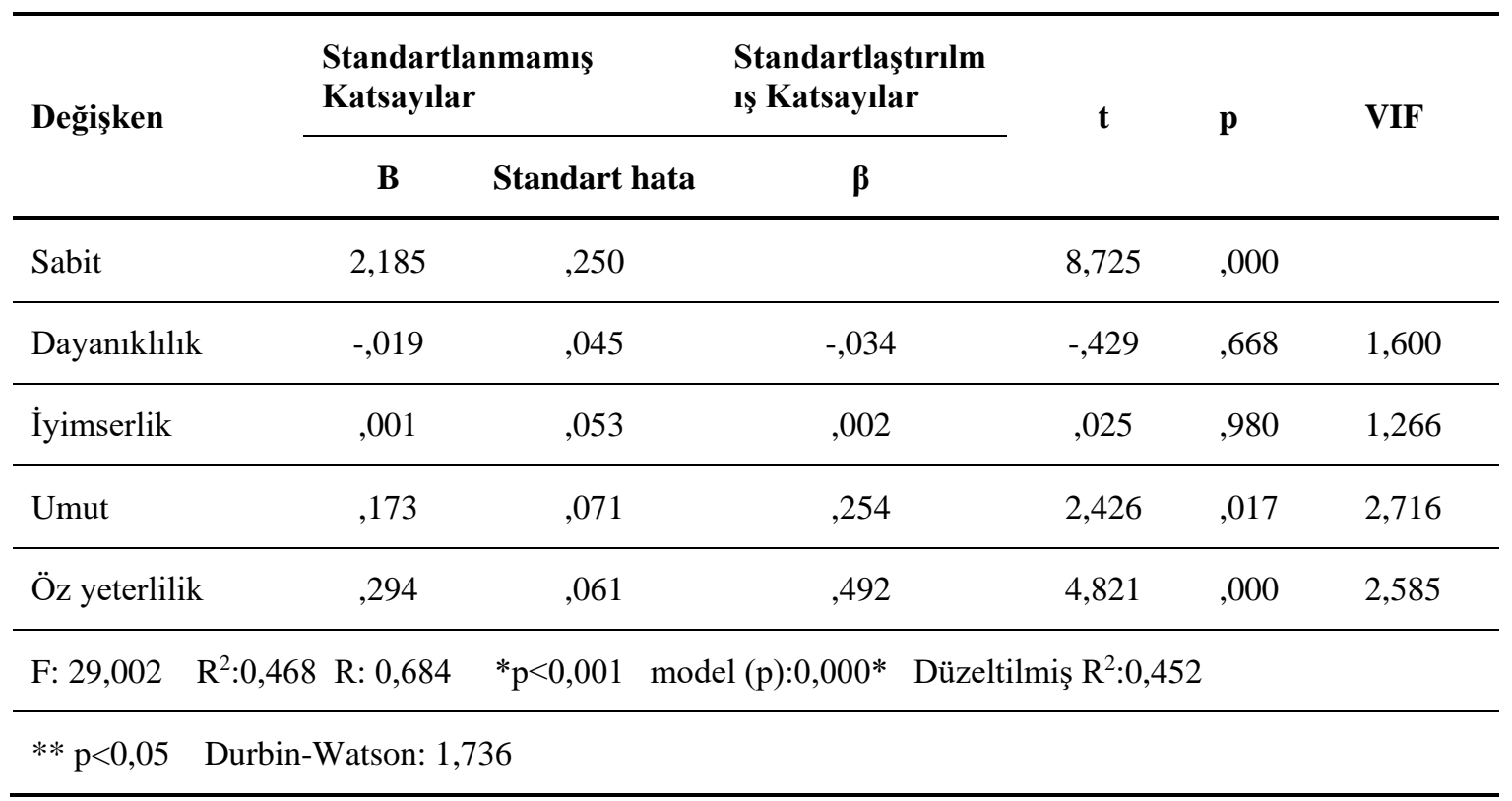

Çoklu regresyon analizi (Alpar, 2018) modeli ( $\left.\mathrm{Y}=\mathrm{a}+\mathrm{bX} \mathrm{X}_{1}+\mathrm{c} \mathrm{X}_{2}+\mathrm{dX}_{3}+\ldots\right)$ şeklinde tanımlanmaktadır. Tablo 6 incelendiğinde kurulan çoklu regresyon analizi modeli istatiksel olarak anlamlıdır ( $\mathrm{F}: 29,002$; p:0,000). Regresyon katsayılarının anlamlılığını işaret eden $\mathrm{t}$ istatistik değerleri dayanıklılık (t:-0,429; p:0,668) ve iyimserlik (t:0,025; p:980) boyutları için anlamsız iken, umut $(\mathrm{t}: 2,426 ; \mathrm{p}: 0,017)$ ve öz yeterlilik $(\mathrm{t}: 4,821 ; \mathrm{p}: 0,000)$ boyutları için istatiksel olarak oldukça anlamlıdır.

Modelin belirlilik katsayısı $\mathrm{R}^{2}: 0,452$ olarak hesaplanmıştır. Bulunan bu sonuca göre; psikolojik sermaye ölçeği alt boyutlarından umut ve öz yeterlilik alt boyutlarının etkisi istatiksel olarak anlamlıdır.

Tahmin edilen modele göre, diğer alt ölçekler sabit iken, umut düzeylerindeki bir birimlik artış performans algısında 0,173'birimlik artışı ve öz yeterlilik düzeylerindeki bir birimlik artış bağımlı değişkende 0,294'lük bir artışı sağlamaktadır. Ölçek alt boyutlarında umut $(\mathrm{t}: 2.426 ; \mathrm{p}: 0,017)$ ve öz yeterlilik $(\mathrm{t}: 4,821 ; \mathrm{p}: 0,000)$ değişkenlerinin performans algıları üzerinde tekil etkileri istatiksel olarak anlamlı ve pozitif yönlü olduğu belirlenmiştir. Bu sonuçlar Tablo 
2'de belirtilen $\mathrm{H}_{1 \mathrm{c}}$ ile $\mathrm{H}_{1 \mathrm{~d}}$ hipotezlerini desteklemektedir. Elde edilen veriler doğrultusunda çoklu regresyon analizi (Alpar, 2018) modeli $\left(\mathrm{Y}=\mathrm{a}+\mathrm{bX} 1+\mathrm{c} \mathrm{X}_{2}+\mathrm{dX}_{3}+\ldots\right)$ ise; $\mathrm{a}=2,185 ; \mathrm{b}=-, 019 ; \mathrm{c}=, 001$ $\mathrm{d}=, 173$ ve $\mathrm{e}=, 294$ olmak üzere, $\mathrm{Y}=2,2185-0,019 \mathrm{X}_{1}+0,001 \mathrm{X}_{2}+0,173 \mathrm{X}_{3}+0,294 \mathrm{X}_{4}$ olarak kurulabilir $\left(X_{1}=\right.$ iyimserlik; $X_{2}=$ psikolojik dayanıklılık; $X_{3}=$ umut; $X_{4}=0 \ddot{z}$ yeterlilik).

$\mathrm{Bu}$ çalışmada yapılan analiz sonuçları aşağıda verilen özet sunumdan da görüleceği gibi literatürü destekler niteliktedir (Tablo 7). Ayrıca Stajkovic \& Luthans (1998b) 114 araştırmay1 imceledikleri meta analiz sonuçlarına göre iş performansı ile öz yeterlilik arasında anlamlı ve pozitif bir ilişki bulunmuştur. $\mathrm{Bu}$ bulgular dikkate alındı̆̆ında psikolojik sermayenin çalışanlarının performansının anlamlı ve pozitif yönde etkilediği sonucu ortaya çıkmış olmaktadır.

Tablo 7: Psikolojik Sermayenin Performansa Etkisi Alan Yazını Araştırması

\begin{tabular}{|c|c|c|c|}
\hline Ateş vd., (2018) & Lojistik çalışanlarında & $\begin{array}{l}\text { Umut }(B=127, \quad P<, 000) \quad \text { Öz } \\
\text { Yeterlilik }(B=, 117 \quad \mathrm{P}<, 000)\end{array}$ & İş performans1 \\
\hline Korkmazer vd., (2016) & $\begin{array}{l}\text { Sağlık çalışanları } \\
\text { kapsamında }\end{array}$ & $\begin{array}{l}\text { Umut (B:0,314; P:0,005) ve Öz } \\
\text { Yeterlilik (B:0,227; P:0,012) }\end{array}$ & Çalışan performansı \\
\hline Karatepe vd., (2018) & Hemşireler üzerinde & Öz Yeterliliğin $(\mathrm{B}=, 460 ; \mathrm{P}<, 000)$ & Bireysel performans \\
\hline Yeşil vd., (2016) & Bankacılık sektöründe & $\begin{array}{ll}\text { İyimserlik } & \text { (B:0,154; } \quad \text { P:0,039), } \\
\text { Umut } & \text { (B:0,273; } \quad \text { P:0,015) } \\
\text { Dayanıklılık }(\mathrm{B}: 0,260 ; \mathrm{P}: 0,018)\end{array}$ & $\begin{array}{l}\text { Çalışanların } \\
\text { performansı }\end{array}$ \\
\hline Kesen ve Kaya (2016) & Akademisyenler üzerinde & $\begin{array}{l}\text { Umut } \quad(B=, 542 ; \quad P<0,01) \quad V e \\
\text { Psikolojik Dayanıklilık }(B=, 143 ; \\
P<0,05)\end{array}$ & Çalışan performansı \\
\hline Uğur (2017) & Otomotiv sektöründe & $\begin{array}{l}\text { Umut }(B=, 26 ; P<0,01) \text { Ve Öz } \\
\text { Yeterlilik }(B=, 30 ; P<0,00)\end{array}$ & İş performans1 \\
\hline
\end{tabular}

\section{SONUÇ VE ÖNERİLER}

$\mathrm{Bu}$ çalı̧̧ma sağlık çalışanlarında psikolojik sermayenin iş performansına etkisinin ne düzeyde olduğunu belirlemek amacıyla yapılmıştır. Ayrıca çalışmada psikolojik sermaye ölçeği ve iş performansı ölçekleri ortalama puanları ile demografik değişkenler açısından bir farklılık olup olmadığı incelenmiştir. Psikolojik sermaye ölçeği ve iş performansı ölçeği puan ortalamaları neticesinde katılımcıların psikolojik sermaye ve iş performansı düzeylerinin yüksek düzeyde olduğu ifade edilebilir.

Demografik değişkenler açısından katılımcıların psikolojik sermaye algıları incelendiğinde; psikolojik sermayenin cinsiyet değişkeni olarak erkeklerde, eğitim durumu açısından lisans mezunlarında, toplam mesleki yıl ve bulundukları kurumda çalışma süresi dikkate alındığında 1-5 yıl arası olanlarda, çalışma statüsü açısından yardımcı sağlık personeli olarak çalışanlarda diğer gruplara göre anlamlı düzeyde daha yüksek olduğu belirlenmiştir. İş performansı ölçeği ile çalışma statüsü arasında anlamlı bir fark belirlenirken, cinsiyet, medeni durum, yaş, eğitim durumu, toplam mesleki yıl ve bulundukları kurumda çalışma süresi dikkate alındığında istatiksel olarak anlamlı bir fark saptanmamıştır. Katılımcıların psikolojik sermaye düzeyleri ile iş performansı arasında istatiksel açıdan anlamlı ve pozitif yönlü bir ilişki 
mevcuttur. Buna göre; katılımcıların psikolojik sermaye düzeyleri arttıkça aynı şekilde iş performansının da artacağ

Psikolojik sermayenin iş performansına etkisi regresyon analizi yöntemi ile test edilmiş ve işgörenlerin psikolojik sermaye düzeylerinin iş performansı üzerinde anlamlı ve pozitif bir etkisinin olduğu gözlenmiştir. Katılımcıların psikolojik sermaye düzeylerindeki artışla performanslarını da olumlu yönde artıracağı söylenebilir. Psikolojik sermaye ölçeği alt boyutlarının iş performansına etkisini belirlemek amaçlı yapılan analizlerde; ölçek alt boyutlarından umut ve öz yeterliliğin iş performansını anlamlı ve pozitif yönde etkilediği belirlenmiştir. Buna göre; katılımcıların umut ve öz yeterlilik düzeylerinin artmasıyla iş performanslarının da olumlu bir şekilde artacağı söylenebilir.

Çalışmanın bulguları literatürü ile uyum içerisindedir ve rekabet ortamının daha da

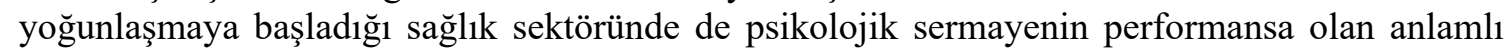
etkisi ortaya konmuştur. Bu bağlamda istenilen hedeflere ulaşmak için gösterilecek performansın bir üst düzeye taşınmasında psikolojik sermayenin de önemli olduğunun ortaya çıktığı ileri sürülebilir. Çalışanların performanslarını yükseltmeye yönelik yapılacak olan faaliyetler çerçevesinde araştırma bulguları ve literatür dikkate alındığında çalışanların psikolojik sermaye düzeylerinin arttırmaya yönelik faaliyetler, etkinlikler, çalışanlara moral verici eğitim programları yapılması önerilebilir.

Yaşanan hızlı değişimler ve küresel rekabet ortamı düşünüldügünde bireylerin işe alım sürecinde yapılan kişisel testlerde psikolojik sermaye düzeylerini belirlemeye yönelik testler uygulanabilir. Böylelikle henüz eleman seçiminde psikolojik sermaye algısı yüksek çalışanların seçimiyle işletmelerin nitelikli insan kaynakları bağlamında bir avantaj sağlamalarının mümkün olabilir Gerek psikolojik sermaye gerekse performans anlamında çalışanlar arasında farkındalığı canlı tutmak anlamında işgörenlere belirli aralıklarla geri bildirimde bulunulabilir.

Alan yazınında farklı sektörlerde yapılan araştırmalarda psikolojik sermayenin performansa etkisi ortaya konulmuştur. Sağlık sektöründe ise bu konuda yapılan çalışmaların yeterli sayıda olmadığı görülmüştür. $\mathrm{Bu}$ bağlamda yapılan çalışmanın özelikle sağlık sektöründeki incelemelerde öncü bir model olacağı düşünülmektedir. Araştırma bulgularında bulunan psikolojik sermaye ve iş performansı ölçekleri puan ortalamalarının yüksek düzeyde olması çalışanların psikolojik sermaye ve iş performansı düzeylerinde iyileştirme çalışmalarının yapılmayacağı anlamına gelmemelidir. Rekabet ortamında ayakta kalabilmek ve kurum olarak büyümeyi hedefleyen işletmelerin psikolojik sermaye ve performans çalışmalarında iyileştirmelerin sürekliliğinin sağlanması gerekmektedir.

Her araştırma olduğu gibi bu araştırmanında kısıtları bulunmaktadır. Araştırmanın Hatay ilinde iki özel hastaneden elde edilen veriler ile yapılmış olması ve katılımcıların dürüst ve samimi bir şekilde anketleri cevaplamış olması varsayımı araştırmanın kısıtları arasında yer almaktadır. $\mathrm{Bu}$ nedenle araştırma sonuçları ile genelleme yapılamaz. Ancak yukarıdaki önerilerin bu kurumlar kapsamında uygulanmasının hem bireysel hem de kurumsal anlamda performans artışını netice vereceği ifade edilebilir. Araştırmanın kamu-özel kuruluşlar dâhilinde farklı coğrafi bölgeleri de kapsayacak şekilde daha geniş kitlelere yapılması ve sonuçların mukayese edilmesi önerilmektedir. Araştırma dâhilinde geliştirilen öneriler özel hastanelerden elde edilen veriler çerçevesince belirtilmiştir. Araştırma dâhilinde geliştirilen önerilerin uygulamada noktasında yalnızca özel hastanelere yönelik olarak kalmaması, kamu hastaneleri için de faydalı olabileceği göz ardı edilmemelidir. Dolayısıyla sağlık sektörünün sayıca büyük bir çoğunluğunu oluşturan kamu hastanelerinde de geliştirilen önerilerin uygulanabileceği söylenebilir. Çalışmanın hem alan yazın ve öneriler bağlamında diğer araştırmacılara ve araştırma bulguları çerçevesinde uygulamacılara katkı sağlayacağı düşünülmektedir. Çalışma içerisinde öncelikle psikolojik sermaye ve iş performansı kavramlarına yer verilmiş olup araştırmanın bulguları ile alan araştırmacılarına katkı sağlayacağı düşünülmektedir. 


\section{KAYNAKÇA}

Akçay, H.V. (2012). Pozitif psikolojik sermayenin iş tatmini ile ilişkisi. KSÜ İIBF Dergisi, 2(1), 123-140.

Akdemir, B. ve Açan M.A. (2017). Psikolojik sermaye ve iş tatmini ilişkisini belirlemeye yönelik bir araştırma. Akademik Yaklaşımlar Dergisi, 8(2), 57-79.

Alpar, R. (2018). Spor, sağlık ve eğitim bilimlerinde örneklerle uygulamalı istatistik ve geçerlilik-güvenirlik. Ankara: Detay Yayıncilık.

Argon, T. ve Tükel, H. (2016). Maarif müfettişlerinin örgütsel psikolojik sermaye algıları ve tükenmişlik düzeylerinin incelemesi. Çağdaş Yönetim Bilimleri Dergisi, 1(1), 1-16.

Ateş, M., Turgut, H., \& Çelik, M. (2018). Psikolojik sermayenin iş performansına etkisinde örgütsel özdeşleşmenin aracılık rolü. Uluslararası İktisadi ve İdari İncelemeler Dergisi, 17. UiK Özel Sayısı, 81-798.

Atlı, Y. ve Yücel, N. (2018). Sağlık kurumları, sağlık kurumlarında marka ve Elazı̆̆ ili sağlık sektörü. Fırat Üniversitesi İ̈BF Uluslararasi İktisadi ve İdari Bilimler Dergisi, 2(2), 45-64.

Büte, M. (2011). Etik iklim, örgütsel güven ve bireysel performans arasındaki ilişki. Atatürk Üniversitesi İktisadi ve İdari Bilimler Dergisi, 25(1), 171-192.

Büyükgöze, H. (2014). Lise Öğretmenlerinin Görüşlerine Göre Algllanan Örgütsel Destek ve Psikolojik Sermaye İlişkisi, Yüksek Lisans Tezi, Ankara: Hacettepe Üniversitesi Eğitim Bilimleri Enstitüsü.

Cömert, Y. ve Yürür, S. (2017). Pozitif psikolojik sermayenin bir belirleyicisi olarak algılanan örgütsel desteğin rolü. İsletme ve İktisat Çalışmaları Dergisi, 5(3), 17-34.

Çetin, F. ve Basım, H.N. (2012). Örgütsel psikolojik sermaye: Bir ölçek uyarlama çalışması. Amme İdaresi Dergisi, $45(1), 121-137$.

Durrah, O., Al-Tobasi, A., Abu A'aqoulah, A., \& Ahmad, M., (2016). The Impact of the Psychological Capital on Job Performance: A Case Study on Faculty Members at Philadelphia University. International Review of Management and Marketing, 6, 183-191.

Enderoğlu, G.E. (2018). Bilişim sektöründe çalışan bireylerde pozitif psikolojik sermaye ile tükenmişlik arasındaki ilişkinin incelenmesi. Yüksek Lisans Tezi, İstanbul: Haliç Üniversitesi Sosyal Bilimler Enstitüsü.

Erkmen, T. ve Esen E. (2013). Psikolojik Sermaye Ölçeğinin Geçerlilik ve Güvenilirlik Çalışması. Öneri Dergisi, 39(10),23-30.

Erkmen, T. ve Esen, E. (2012). Psikolojik sermaye konusunda 2003-2011 yıllarında yapılan çalışmaların kategorik olarak incelenmesi. Mustafa Kemal Üniversitesi Sosyal Bilimler Enstitüsü Dergisi, 9(19), 89-103.

Erkuş, A. ve Fındıklı, M. A. (2013). Psikolojik sermayenin iş tatmini, iş performansı ve işten ayrılma niyeti üzerindeki etkisine yönelik bir araştırma. Journal of the School of Business Administration, 42(2), 302-318.

Ertuğrul, İ. (2006). Akademik performans değerlendirmede bulanık mantık yaklaşımı. Atatürk Üniversitesi İktisadi ve İdari Bilimler Dergisi, 20(1), 155 - 176.

Harvey, D. ve Bowin, R. B. (1996). Human resource management an experiential approach. New Jersey: Prentice Hall..

Helvacı, M.A. (2002). Performans yönetimi sürecinde değerlendirmenin önemi'. Ankara Üniversitesi Ĕ̆itim Bilimleri Fakültesi Dergisi, 35(5), 155-169.

Karadal, H. ve Özsungur, F. (2017). Hizmet inovasyon davranışı ile psikolojik sermaye ve etik liderlik ilişkisinin incelenmesi: Adana örneği. Uluslararası Yönetim İktisat ve İşletme Dergisi, Özel Sayısı, 663-672.

Karatepe H., Kuşcu, N.F., Atik, D., Karaman, M., Öztürk, T.Y., \& Şen, H. T. (2018). Psikolojik sermayenin bireysel performansa etkisi: Hemşireler üzerinde bir araştırma. 2. Uluslararası 12. Ulusal Sağlık ve Hastane İdare Kongresi, 1844-50. (11-13 Ekim 2018).

Kaya, A., Balay, R. ve Demirci, Z. (2014). Ortaöğretimde görev yapan öğretmenlerin psikolojik sermaye düzeylerinin incelenmesi (Şanlıurfa ili örneği). Elektronik Sosyal Bilimler Dergisi, 13(48), 47-68.

Keleş, H.N. (2011). Pozitif psikolojik sermaye: Tanımı, bileşenleri ve örgüt yönetimine etkileri. Organizasyon ve Yönetim Bilimleri Dergisi, 3(2), 343-350.

Kesen, M. ve Kaya, N. (2016). Çalışan performansının örgütsel imaj ve psikolojik sermaye bağlamında incelenmesi: Vakıf üniversiteleri örneği. International Journal Of Social Science, 46, 187-198. 
Kılınç, E. ve Paksoy, H. (2017). Sağlık çalışanlarında performans algı düzeyinin bazı sosyo-demografik değişkenlere göre incelenmesi. Selçuk Üniversitesi Sosyal Bilimler Meslek Yüksekokulu Dergisi, 20(2), 151-159.

Korkmazer, F., Ekingen, E., \& Yıldız, A. (2016). Psikolojik sermayenin çalışan performansına Etkisi: Sağlık çalışanları üzerinde bir araştırma. Hacettepe Sağlık İdaresi Dergisi, 19(3), 271-281.

Kutanis, R.Ö., Oruç, E. (2014). Pozitif örgütsel davranış ve pozitif psikolojik sermaye üzerine kavramsal bir inceleme. The Journal of Happiness \& Well-Being, 2(2), 145-159.

Luthans F., Avolio B.J., Avey J.B., \& Norman S.M. (2007). Positive psychological capital: Measurement and relationship with performance and Satisfaction. Personnel Psychology, 60(3), 541-572.

Luthans, F. (2002). Positive Organizational Behavior: developing and managing psychological strengths. Academy of Management Executive, 16(1), 57-72.

Luthans, F., Avey, J.B., Avolio, B.J., Norman, S.M., \& Combs, G.M., (2006). Psychological Capital Development: Toward a Micro Intervention. Journal of Organizational Behavior, 27(3), 387-393.

Luthans, F., Luthans, K.W., \& Luthans, B.C. (2004). Positive psychological capital: beyond human and social capital. Business Horizons 47(1).45-50.

Luthans, F., Youssef,C.M., \& Avolio, B.J. (2007). Psychological capital: Developing the human competitive edge. Oxford:Oxford University Press.

Luthans, S.M., Norman, B.J., \& Avolio, J.B. (2008). The mediating role of psychological capital in the supportive organizational climate-employee performance relationship. Journal of Organizational Behavior, 29, 219-238.

Macit, M. (2015). İşkoliklik, iş-aile çatışması ve tükenmişlik ilişkileri üzerine bir araştırma, Doktora Tezi, Tokat: Gaziosmanpaşa Üniversitesi Sosyal Bilimler Enstitüsü.

Öğe, S. ve Kaplan, M. (2017). Girişimcilik eğitiminde pozitif psikolojik sermayenin rolü üzerine bir değerlendirme. Balkan and Near Eastern Journal of Social Sciences, 3(4), 28-33.

Öğüt, A. ve Kaplan, M. (2015). Sağlık sektöründe psikolojik sermayenin iş performansı üzerindeki etkisi. Sosyal Ekonomik Araştırmalar Dergisi, 30, 87-99.

Örgün, E., Keskin, E., \& Erol, G. (2017). Otel mutfağı çalışanlarının psikolojik sermaye düzeyleri üzerine bir araştırma. Journal Of Recreation And Tourism Research, 4(4), 174-183.

Özer, P.S., Topaloğlu, T., \& Özmen, Ö.N.T. (2013). Destekleyici örgüt ikliminin, psikolojik sermaye ile iş doyumu ilişkisinde düzenleyici etkisi. Ege Akademik Bakıs, 13(4), 437-447.

Özkan, O.S. (2018). Psikolojik sermayenin bireysel performans üzerindeki etkisinde birey-örgüt uyumunun aracılı rolü. Doktora Tezi, Ankara: Türk Hava Kurumu Üniversitesi Sosyal Bilimler Enstitüsü.

Peterson, S.J., Luthans, F., Avolio, B.J., Walumbwa, F.O., \& Zhang, Z. (2011). Psychological capital and employee performance: A latent growth modeling approach. Personnel Psychology, 64, 427-50.

Saithong-in, S. (2016). Psychological Capital and Job Performance: An Empirical Research of Certified Public Accountants (Cpas) in Thailand. The Business and Management Review, 7(5), 499-506.

Saygılı, M., Erigüç, G., \& Özer, Ö. (2016). Sağlık çalışanlarının örgütsel sessizlik ve çalışan performansı düzeylerinin belirlenmesi. International Journal Of Social Science, 49, 485-500.

Sonnentag, S. ve Frese, M. (2002). Performance Concepts and Performance Theory. Editör Sabine Sonnentag. Psychological Management of Individual Performance içinde (1-25). West Sussex:John Wiley \& Sons, Ltd.

Stajikovic, A. and Luthans, F. (1998a). Social cognitive theory and self-efficacy: Going beyond traditional motivational and behavioral approaches. Organizational Dynamics, 26, 62-74.

Stajkovic, A.D., \& Luthans, F. (1998b). Self-efficacy and work-related performance: A meta-analysis. Psychological Bulletin, 124, 240-261.

Tabachnick, L.S., \& Fidell, B.G. (2013). Using multivariate statistics (Sixth Ed.) Pearson, Boston.

Tekin, O. (2018). Duygusal emek ile iş doyumu arasındaki ilişkide psikolojik sermayenin aracılık rolü: Finans sektörü örneği, Yüksek Lisans Tezi, Kayseri: Erciyes Üniversitesi Sosyal Bilimler Enstitüsü.

Tekingündüz, S., Top, M., \& Seçkin, M. (2015). İş tatmini, performans, iş stresi ve işten ayrılma niyeti arasındaki ilişkilerin incelenmesi: Hastane örneği. Verimlilik Dergisi, 4, 39-64.

Tercan, S. (2017). Otantik liderliğin çalışan motivasyonu ve iş performansina etkisi, Yüksek Lisans Tezi, İstanbul: İstanbul Arel Üniversitesi Sosyal Bilimler Enstitüsü. 
Topkaya, Ö. ve Korucu, G . (2018). Hizmetler sektöründe kadın çalışanların iş tatmin düzeyleri ve pozitif psikolojik sermaye arasındaki ilişkiye yönelik bir alan araştırması. Çanakkale Onsekiz Mart Üniversitesi Uluslararası Sosyal Bilimler Dergisi, 3(1), 31-52.

Turgut, M., Yeşilaydın, G., Özkan, Ş., \& Aldoğan Ugurluoğlu, E. (2016). Psikolojik sermaye ve örgütsel bağlllık arasındaki ilişki: Bir kamu hastanesi örneği. 10. Sağlık ve Hastane İdaresi Kongresi, Bildiri Kitabı.

Türesin Tetik, H., Oral A.L., \& Köse, S. (2017). Psikolojik sermaye ile iş doyumu ve performans ilişkisi: Türkiye'de yapılan araştırmalar üzerinden bir meta analizi. Atatürk Üniversitesi İktisadi ve İdari Bilimler Dergisi, 32(2), $289-314$.

Uğan, Ç., Karakaya, F., \& Nayır, Y. (2018). Psikolojik sermayenin işgören performansı ve iş stresine etkisi. 2. Uluslararas1 12. Ulusal Sağlık ve Hastane İdare Kongresi, ss. 1868-75. (11-13 Ekim 2018).

Uğur, D. (2017). Psikolojik sermaye ve örgütsel adaletin iş performansı üzerindeki etkisi, Yüksek Lisans Tezi, İstanbul: Y1ldız Teknik Üniversitesi Sosyal Bilimler Enstitüsü.

Uğurlu Kara, A. (2014). Pozitif psikolojik sermaye ile bireysel performans ilişkisi: Tarım Kredi Koperatifleri Merkez Birliği Örneği, Yüksek Lisans Tezi, Ankara: Gazi Üniversitesi Sosyal Bilimler Enstitüsü.

Yeşil S., Yetiş E., \& Telli S. (2016). Psikolojik sermaye ve çalışanlar üzerinde etkisi: Banka sektöründe bir alan çalışması. Internatonal Journal Of Academic Value Studies, 2(2), 2540.

Yıldız, H. \& Örücü E. (2016). Sağlık sektörü çalışanlarının pozitif psikolojik sermaye düzeylerinin belirlenmesine yönelik bir araştırma. Yönetim ve Ekonomi Araştırmaları Dergisi, 14(1), 269-285. 


\section{Extended Summary}

\section{The Effect of Psychological Capital on Business Performance: An Application in Health Care Workers}

This descriptive research was carried out with screening model. The study aims to determine the effect of psychological capital and its dimensions on job performance. The population of the study consisted of 300 health workers working in two private hospitals in Hatay province.

Personal information form, Psychological Capital Scale and Job Performance Scale were used to collect the data. The personal information form was prepared by the researchers to determine the gender, marital status, age, educational level, total professional year, working time in the institution and the working status of the participants. Psychological Capital Scale was developed by Luthans et al. (2007) in order to measure the psychological development of individuals. The scale was adapted to Turkish by Çetin and Basım (2012). Psychological Capital Scale consists of four sub-dimensions which namely resiliency, optimism, hope and selfefficacy. A Likert-type scale was used required an individual to respond to a series of statements by indicating whether he or she strongly agrees (6), to strongly disagrees (1). The construct validity of the four-factor structure of the psychological capital scale was tested by confirmatory factor analysis (CFA). The goodness of fit values obtained as a result of DFA are as follows; $[\chi 2=302,326 ; \quad \mathrm{Sd}=173 ; \quad \chi 2 / \mathrm{Sd}=1,84 ; \quad \mathrm{AGFI}=0,86 ; \quad \mathrm{GFI}=0,88 ; \quad \mathrm{CFI}=0,94 ; \quad \mathrm{IFI}=0,95 ;$ RMSEA=0,06; RMR=0,07]. The four-factor structure of the psychological capital scale was confirmed by looking at the goodness of fit values obtained from the CFA analysis, and it was concluded that the scale was a valid scale.

The job performance scale was developed by Tercan (2017) in order to determine the performance perception levels of individuals. The scoring of the Likert-type scale ranges from "(1) Never Reflecting "to "(5) Completely Reflecting. The construct validity of the one-factor structure of the performance scale was tested by confirmatory factor analysis (CFA). The goodness of fit values obtained as a result of DFA are as follows; $[\chi 2=64,673 ; \mathrm{Sd}=34$; $\chi 2 / \mathrm{Sd}=1,80 ; \quad \mathrm{AGFI}=0,92 ; \quad \mathrm{GFI}=0,96 ; \quad \mathrm{CFI}=0,95 ; \quad \mathrm{IFI}=0,95 ; \quad \mathrm{RMSEA}=0,07 ; \quad \mathrm{RMR}=0,04]$. According to the goodness of fit values obtained from the CFA analysis, the single-factor structure of the business performance scale was confirmed and it was concluded that the scale was a valid scale.

SPSS 22 package program was used to evaluate the data. Normality test was performed before the analysis. Skewness and Kurtosis values of the data obtained from psychological capital and job performance scale variables were found to be between -1.5 and +1.5 as a result of the normality test (Table 2). According to Tabachnick and Fidell (2013), if the Skewness and Kurtosis values of the scale variables are between -1.5 and +1.5 , they provide the normal distribution condition. Analysis methods used in data analysis; were number-percentage calculation, independent sample $\mathrm{t}$ test, one-way analysis of variance, Pearson correlation analysis, simple and multiple regression analysis methods. The Cronbach's Alpha value of the Psychological Capital scale was 0.92, the Cronbach's Alpha values of the subdimensions of Psychological Capital ranged from 0.64 to 0.91 . The Cronbach's alpha value of the job performance scale was 0.89 .

Before starting the research, the ethics committee permission of E.10371 dated 14/03/2018 and written permission were obtained from the Scientific Research Ethics Committee of Kahramanmaraş Sütçü İmam University. Participation in the study was done on a voluntary basis. Firstly, the participants were informed about the aim of the research and they 
were be given guarantee that the information would be used only for scientific purposes. $70,1 \%$ of the participants were female and $29.9 \%$ were male. $50,4 \%$ of the health workers included in the study were single and $49,6 \%$ were married. $35,8 \%$ of the participants were $23-28$ years of age and $35.8 \%$ were college degree. $42,3 \%$ of the participants were between $1-5$ years, $25.3 \%$ of them were between 6-10 years and $13.1 \%$ of them were between 11-15 years. In terms of working time, $47.4 \%$ of them were $1-5$ years, $32.8 \%$ of them were $6-10$ years and $19.7 \%$ of them were less than 1 year.

The mean score of psychological capital was $\bar{X}=4.71 \pm 0.63$. The mean score of the subscale of the resiliency scale was $\bar{X}=4.78 \pm 0.91$; The mean score of the sub-dimension of optimism was $\overline{\mathrm{X}}=4.00 \pm 0.70$; The average score of hope sub-dimension was $\overline{\mathrm{X}}=5.00 \pm 0.75$ and the average score of self-efficacy sub-dimension was $\bar{X}=5.05 \pm 0.86$. The average job performance scale score was $\overline{\mathrm{X}}=4.44 \pm 0.51$. When the subscales of the scale were examined, the resiliency, self-efficacy and hope sub-dimensions were above the average value of the psychological capital but optimism sub-dimension, was below the average value.

There was a statistically significant difference between the mean scores of psychological capital scale in terms of gender, education level, total professional year, working time and working status in the institution but no relation was found between the mean of psychological capital scale in terms of marital status and age. A significant difference was found between job performance scale according to working status. No statistically significant evidence is observed indicating differences in job performance level in terms of gender, marital status, education level, age, total professional year and duration of work in the institution.

There was a statistically significant and positive relationship between psychological capital scale and job performance scale (r: 0.622; $\mathrm{p}<0.001$ ). Simple regression analysis was performed to determine the effect of psychological capital subscales on job performance. This value indicated that approximately 39\% of the variance in performance scores can be predicted from psychological capital perception. It was determined that psychological capital had a statistically significant and positive effect on job performance $(\beta: 0.503 ; p<0,01)$. Multiple regression analysis was conducted to determine the effect of psychological capital subdimensions on job performance. According the results, it indicated that approximately $47 \%$ of the variance in performance scores can be predicted from subdimensions of psychological capital perception. Therefore, the effect of hope and self-efficacy sub-dimensions on job performance was found to be statistically significant and positive.

In this study, it was found that psychological capital and job performance perceptions of health workers were high and in line with the literature. In terms of demographic (male participants, undergraduate graduates, the total professional year of 1-5 years, the working period of 1-5 years in their institution variables) the psychological capital perceptions were higher. Moreover, psychological capital perceptions were higher for permanent staff than contracted health workers. It was found that the performance perception of midwives was also higher than other groups.

According to the results it can be inferred that psychological capital had a statistically significant and positive effect on work performance. Furthermore, it was determined that the psychological capital sub-dimensions of hope and self-efficacy had a statistically significant and positive effect on job performance, but resiliency and optimism sub-dimension did not significantly affect job performance. 